\title{
Kekuatan Memori dan (Ketidak)Mungkinan Pengampunan dalam Novel Hanauzumi Karya Jun'ichi Watanabe
}

\author{
Intannia Cahyasari \\ Linguistik Terapan, Program Pascasarjana Universitas Negeri Yogyakarta \\ intannia_c@yahoo.co.id
}

\begin{abstract}
Abstrak
Penelitian ini menganalisis pembentukan memori dan pengampunan sebagai alat yang digunakan Ginko Ogino dalam membentuk wacana kebenaran, sehingga memberinya kekuatan untuk memperjuangkan hak keadilan dirinya dan perempuan lainnya sebagai bentuk kritik terhadap sisa-sisa pengalaman yang dialami masyarakat Jepang selama Politik Isolasi lebih dari 350 tahun yang masih hidup dalam kehangatan tradisi dan keheningan adat yang terdapat dalam novel Hanaurumi. Metode yang digunakan dalam penelitian ini adalah deskriptif kualitatif dengan menggunakan sebagian teori postmemory Marianne Hirsch dan teori kekuasaan/pengetahuan Michael Foucault. Hasil analisis menunjukkan bahwa pembentukan memori Ginko berasal dari eksploitasi seks, gender, pendidikan maupun hak politik yang menimpa dirinya. Wacana yang digunakan Ginko untuk merepresentasikan praktik kekuasaan dari sudut pandangnya sebagai dokter maupun sebagai perempuan. Transmisi pengetahuan dan pengalaman tersebut merupakan reaksi dari masa lalu Ginko sebagai post generasi.
\end{abstract}

Kata Kunci: Memori, Kekuasaan, Pengampunan, Traumatis, Restorasi Meiji

\begin{abstract}
This study analyze the formation of memory and the forgiveness as a tool used by Ginko Ogino in shaping the discourse of truth, thus giving him the strength to fight for his and other's justice rights as a form of criticism of the remnants of experience experienced by Japanese society during the Isolation Politics of over 350 years still lived in the warmth of tradition and in the silence of custom contained in the Hanauzumi's novel. The method used in this research is descriptive qualitative by using some postmemory theory of Marianne Hirsch and theory of power/knowledge of Michael Foucault. The results of the analysis show that the formation of Ginko's memory comes from the exploitation of sex, gender, education and political rights that befall him. The discourse used by Ginko to represent the practice of power from his point of view as a doctor or as a woman. Transmission of knowledge and experience is a reaction from Ginko's past as a postgeneration.
\end{abstract}

Keywords: Pop-islamic fiction, Mizan Publisher, spoken and unspoken, silences.

\section{Pendahuluan}

Jun’ichi Watanabe adalah seorang penulis Jepang yang mempunyai latar belakang kedokteran. Penulis kelahiran Hokkaidou, Jepang, tahun 1933 ini memulai ketertarikannya pada dunia kepenulisan saat masih bersekolah di sekolah menengah. Setelah lulus dan masuk kedokteran di Universitas Sapporo, Hokkaidou,
Watanabe mulai mencoba menerbitkan tulisantulisannya pada beberapa majalah sastra. Setelah lulus dari kedokteran, ia membuka praktik kedokterannya sebagai ahli bedah ortopedi, namun praktiknya itu ia tinggalkan dan lebih memilih untuk menekuni dunia kepenulisan. Sejak 1969, ia pindah ke Tokyo dan mencurahkan semua perhatiannya sebagai penulis. 
Sejumlah karyanya berupa novel biografis dan beberapa karyanya juga merepresentasikan dunia kedokteran sebagai latar belakang penulisan. Dengan latat belakang kedokteran yang dimilikinya telah mempengaruhi pilihan tema yang diangkat dalam karyanya. Salah satunya adalah novel Hanauðumi yang memiliki alur memikat perhatian dengan mengusung tema emansipasi perempuan. Novel ini menggambarkan eksistensi dan perjuangan perempuan pada struktur sosial dan pendidikan yang dikemas dengan adanya keterbukaan zaman pada waktu itu. Latar belakang waktu yang diangkat dalam novel yaitu peralihan dari masa Tokugawa ke masa Kekaisaran Meiji. Dengan dibukanya Politik Isolasi yang dianut penguasa sebelumnya selama lebih dari 350 tahun membuat Jepang menutup diri dari dunia luar, menyebabkan bertemunya budaya Jepang dengan budaya Barat pada masa Restorasi Meiji. Hal tersebut mempunyai pengaruh yang berarti terhadap hubungan gender di dalam masyarakat. Sistem patriarki yang selama ini subur hidup di berbagai lini masyarakat mulai mendapatkan kecaman. Golongan perempuan dan para aktivis gender mempertanyakan belum terpenuhinya keadilan bagi perempuan dalam pemenuhan hak -haknya. Mulai dari hak untuk memperoleh pendidikan hingga hak menyuarakan politiknya agar setara dengan hak yang dimiliki laki-laki. Berbagai usaha dan perjuangan telah dilakukan, namun konstruksi sosial yang telah mengakar kuat selama ratusan tahun tidak mudah untuk dirubah.
Restorasi Meiji dipuji sebagai zaman peradaban dan pencerahan dan sekaligus memberikan harapan bagi golongan perempuan di Jepang untuk menuntut hak-hak mereka terpenuhi. Restorasi Meiji berarti dimulainya peniruan secara besar-besaran yang dilakukan oleh Jepang terhadap berbagai kebijakan pemerintah dan negara Barat. Hal ini memicu sebuah harapan yang timbul. Jepang memasuki era modernisasi. Namun, apakah hiruk pikuk modernisasi tersebut terasa sampai ke lini kehidupan masyarakat kecil dan begitu saja memberikan kesempatan terbuka bagi golongan perempuan? Pertanyaan tersebut sesuai dengan pendapat Sik (2015:54) yang menyatakan bahwa interpretasi masa lalu dan tindakan politik penguasa tergantung pada logika bidang. Jika ketidaksetaraan struktural antar bidang sangat ekstrem (misalnya logika politik atau ekonomi mengendalikan proses transmisi memori) sehingga dominan mencegah otonomi yang lain. Sik menambahkan lagi bahwa gagasan tentang budaya politik adalah konsep fenomenologis yang sesungguhnya menjelaskan perilaku politik dengan sikap yang terbentuk dalam proses sosialisasi. Dan gagasan ini sangat erat kaitannya dengan konsep memori kolektif yang telah tertanam di masa lalu. Struktur budaya masyarakat dan politik terbentuk oleh proses pararel sosialisasi politik dan transmisi memori.

Dalam Hanauzumi, yang terbit tahun 1970, Watanabe menyisakan harapan untuk resolusi positif dari sistem patriarki yang telah menjadi budaya selama ratusan tahun. Novel tersebut menyiratkan bahwa masa lalu yang pahit dan tragis tidak dapat dilupakan begitu saja oleh Gin. Pada awalnya me- 
mang tidak ada kesempatan untuk berdamai dan memafkan kesalahan mantan suami serta golongan laki-laki lainnya yang tidak menghargainya sebagai perempuan dan memperlakukannya dengan tidak adil sebagai korban eksploitasi seks, pendidikan maupun hak politik, namun pada akhirnya Gin berhasil berdamai dengan masa lalunya itu. Dan selanjutnya, ada kesempatan penebusan yang dilakukan oleh Gin dengan berjuang mewujudkan cita-citanya meraih profesi dokter sebagai rasa solidaritas sesama perempuan.

Setiap individu pasti selalu terhubung dan berinteraksi dengan individu yang lain. Dan dalam setiap individu juga tidak akan terlepas antara masa lalu dan masa kini. Masa lalu memberikan pengaruh yang signifikan bagi seseorang dalam menjalani hidupnya pada masa kini dan masa mendatang. Selain itu, masa lalu juga cukup efektif dalam memantik perasaan emosional seseorang. Fernanda (2017:2) menyatakan bahwa pengalaman seseorang pada masa lalu adalah memori yang merupakan sesuatu yang berada di luar tubuh baik dialami secara langsung maupun tidak langsung. Memori masa lalu yang ditransmisikan biasanya adalah pengalaman yang bersifat traumatik, karena kesan traumatik memang lebih dominan dan lebih terekam kuat bagi individu. Kesan traumatik inilah yang kemudian ditransmisikan ke generasi selanjutnya.

Nora (1989:7) menjelaskan bahwa memori mengkristal dan menjadi rahasia tersendiri yang telah terjadi pada momen historis tertentu. Titik balik di mana kesadaran akan perpisahan dengan masa lalu yang terikat dengan perasaan bahwa memori telah runtuh - namun runtuh yang sedemikian rupa untuk menimbulkan perwujudan memori di bagian-bagian tertentu di mana rasa kontinuitas historis tetap ada. Memori didorong oleh adanya perubahan dan memori mengatur masa lalu. Di satu sisi, kita menemukan sebuah memori yang terpadu dan diktator - yang tidak sadar, memerintah, kuat, secara spontan mengaktualisasikan. Memori kita tidak ada yang lebih dari sekadar menyaring jejak historis.

Gorska (2016:7-8) menyatakan bahwa memori memainkan peran utama dalam kehidupan individu dan masyarakat. Pada saat bersamaan, individu yang berkembang dalam masyarakat yang terpengaruh budaya masyarakat Barat modern membuat memori kolektif masyarakat lebih bermasalah. Sejarah dan memori bersama tidak seperti yang biasa terjadi dalam proses sosialisasi oleh keluarga dan masyarakat, namun semakin tergantung pada sistem pendidikan dan media. Budaya dan kehidupan sosial mengalami pergeseran dari masa lalu sebagai subjek untuk dipelajari. Kemudian Gorska juga menambahkan bahwa hubungan identitas dan memori tidak dapat dipisahkan. Identitas individu dan masyarakat bergantung pada mengingat dan bagaimana memori dibuat dan iingat bergantung pada identitas.

Hirsch (2008:105-106) menyatakan bahwa keturunan korban selamat (korban dan pelaku) dari peristiwa traumatis besar terhubung sangat dalam dengan kenangan masa lalu generasi sebelumnya yang mereka butuhkan untuk memanggil hubungan memori tersebut dan oleh karena itu, dalam keadaan ekstrim tertentu, ingatan bisa 
ditransmisikan ke orang-orang yang sebenarnya tidak ada di sana atau tidak terlibat langsung dengan peristiwa traumatis tersebut. Pada saat yang sama - dapat diasumsikan bahwa ingatan yang diterima ini berbeda dari ingatan para saksi dan peserta yang sezaman dengan peristiwa traumatis tersebut. Lebih lanjut Hirsch mengungkapkan and yet postmemory is not a movement, method, or idea; I see it, rather, as a structure of inter- and trans-generational transmission of traumatic knowledge and experience. It is a consequence of traumatic recall but (unlike posttraumatic stress disorder) at a generational remove. Transmisi pengetahuan dan pengalaman inilah yang dilakukan oleh tokoh utama dalam novel Hanauzumi sebagai reaksi dari masa lalunya. Namun demikian, berfikir kritis saja terhadap peristiwa traumatis tertentu belum cukup memadai untuk menjelaskan bagaimana kebenaran dan berkuasa menyusun ‘ilmu pengetahuan’ sebagai sesuatu yang normal dalam realitas sosial.

Seseorang dapat menerapkan teori kekuasaan/pengetahuan Michael Foucault untuk menentukan fungsi memori. Foucault, seorang filsuf Prancis dan kritikus sastra terkenal, prihatin dengan cara-cara di mana institusi sosial menjalankan kekuasaan atas orang-orang melalui pengetahuan. Bagi Foucault, pengetahuan merupakan sumber dan produk kekuasaan (Pytko, 2016:61). Syahputra (2010:3) menambahkan pusat pemikiran Foucault terletak bukan pada apa itu kekuasaan, tetapi bagaimana kekuasaan itu bekerja dan dijalankan. Foucault tertarik pada pengetahuan akan manusia dan kekuasaan yang berpengaruh atas manu- sia. Untuk membentuk kebenaran dibutuhkan tenaga sebagai kekuasaan. Karena itulah, menurut Foucault, pengetahuan itu adalah kekuasaan yang bersifat memaksa.

Kekuasaan menghasilkan pengetahuan (dan tidak hanya dengan mendorongnya karena ia melayani kekuasaan atau dengan menerapkannya karena ini berguna). Kekuasaan dan pengetahuan itu secara langsung saling menyiratkan; bahwa tidak ada hubungan kekuasaan tanpa konstitusi korelatif dari bidang pengetahuan, atau pengetahuan yang tidak mengandaikan dan pada saat bersamaan membentuk relasi kekuasaan. Pytko (2016:61-62) menambahkan bahwa karena hubungan kekuasaan dan pengetahuan mengasumsikan saling ketergantungan seharusnya tidak dianggap terpisah. Lebih lanjut lagi, Foucault menggarisbawahi bahwa kekuasaan dan pengetahuan mampu mempengaruhi persepsi kebenaran masyarakat tertentu.

Ingham (2001) memaparkan beberapa pemikiran Foucault dalam karya tulisnya yang salah satunya yaitu Lahirnya Klinik. Klinik menurut Foucault merupakan realitas yang menyimpan banyak misteri bagi terselenggaranya suatu praktik kekuasaan. Rumah sakit dan kedokteran klinis dinilai Foucault sebagai metode terbaik untuk merawat pasien dan melatih para dokter muda. Itulah yang dikatakan Foucault dengan Klinik. Tatapan mata para dokter pada penyakit pasiennya akan menimbulkan kemampuan berbicara. Saat tatapan mata tersebut semakin jelas melihat pada suatu penyakit, maka ia akan berubah menjadi ajaran harus diajarkan dan disebarluaskan pada para dokter dan staff medis lainnya. Tiba-tiba tatapan mata 
menjadi suatu kekuasaan yang dapat melihat bagian tersembunyi dari tubuh pasien.

Oleh karena itu, tujuan dari tulisan ini adalah untuk menyajikan memori dan pengampunan sebagai alat yang digunakan oleh Gin untuk membentuk wacana kebenaran, sehingga memberinya kekuatan untuk memperjuangkan keadilan hak-hak perempuan, hak untuk dirinya maupun untuk perempuan lainnya. Sesuai dengan sebagian teori postmemory Marianne Hirsch dan teori kekuasaan/pengetahuan Michael Foucault, memori dalam Hanauzumi terbukti menjadi alat yang ampuh untuk menghasilkan kenyataan, yang digunakan Gin untuk memunculkan keberaniannya dan menyalurkan semangat perjuangannya. Perceraian Gin dengan mantan suami dan penyakit kelamin yang diderita turut memperkuat percikan semangatnya. Ini juga yang membuat Tomoko sebagai kakak Gin, Ogie, dr. Mannen dan pihakpihak lainnya memberikan dukungan kepada Gin terlepas dari konstruksi masyarakat saat itu. Lebih jauh lagi, ingatan Gin tentang peristiwa pemeriksaan alat kelaminnya yang terinfeksi oleh dokter laki-laki karena saat itu belum ada dokter perempuan di Jepang, menjadi permulaan perjuangan Gin dalam mewujudkan citacitanya sebagai dokter perempuan pertama di Jepang dan berdamai dengan masa lalunya.

Metode yang digunakan dalam penelitian ini adalah deskriptif kualitatif. Raco (2013:1) menyatakan bahwa metode kualitatif merupakan sebuah teknik atau prosedur dan gagasan teoritis. Tujuannya adalah mencari makna terdalam mengenai suatu gejala, masalah, realita serta per- istiwa yang hanya dapat dipahami secara mendalam oleh penelusuran seorang peneliti. Cresswell (2008) menambahkan bahwa data-data penelitian kualitatif berupa kata-kata atau teks yang kemudian dianalisis yang mana hasil analisisnya berupa deskripsi atau gambaran. Peneliti membuat interpretasi terhadap data-data tersebut untuk menangkap makna terdalamnya kemudian melakukan perenungan pribadi (self-reflection) dan menjabarkannya berdasarkan pandangan, pemikiran dan pengetahuan yang dimiliki. Hasil akhir penelitian kualitatif dituangkan dalam bentuk laporan tertulis yang bersifat agak fleksibel karena tidak ada ketentuan bakunya. Dalam penelitian ini peristiwa traumatis tokoh utama digambarkan yang menjadi cikal bakal perjuangannya menjadi dokter perempuan pertama di Jepang.

\section{Pembentukan Memori dan Identitas Sebagai Sumber Kekuatan Gin}

Gin tidak pernah merasa ragu akan pernikahannya. Karena usianya baru enam belas tahun, pikirannya masih dipenuhi harapan-harapan seorang gadis kecil. Sulit sekali mempercayai bahwa tiga tahun kemudian, Gin yang cerdas dan ceria lari dari rumah suaminya dan pulang ke rumah orang tuanya dalam keadaan yang menyedihkan.

「男性はもうこりごりです。お嫁に なぞ一生いけなくてもかまいませ ん。その方がじれだけせいせいする か分かりません」

[Dansei wa mou kori gori desu. Oyome ni nazo issei ikenakutemokamaimasen. Sono hou ga doredake seisei suru ka wakarimasen]

Aku tak mau lagi berbubungan dengan lelaki! Aku takkan menyesal bila aku tak pernab bisa 
menikah lagi. Hidup sendiri adalah kebebasan tertinggi di dunia ini. (Hanauzumi, 1970: 21)

$$
\text { 「一時でも、ちよっとしたことで }
$$
も、うつされたことは同じです」

[ Ichi ji demo, chotto shita koto demo, utsusareta kotow a onaji desu]

Tak peduli betapa pun kecilnya kesalahan suamiku atau meskipun banya dilakukan sekali seumur hidup, yang jelas dia telah memberiku penyakit ini. (Hanaurumi, 1970: 22)

\section{「女だから病気をうつされても、} 子供を産めない体にされても我慢 せよというのですか。熱があって も起きてお姑さんに仕え、夫の機 嫌をとれというのですか」

[Onna dakara byouki wo utsusaretemo, kodomo wo umenai karada ni sarete mo gamanseyo to iu no desuka. Netsu ga attemo okite oshuutome san ni tsukae, otto no kigen wo to iu no desuka]

Lalu, kalau seorang perempuan mendapatkan penyakit dari seorang laki-laki dan tak bisa memiliki anak, dia harus menerimanya begitu saja? Meskipun aku menderita demam, aku tetap harus bangun dari tempat tidur, mematubi segala perintah Ibu mertua kepadaku, dan melakukan segalanya semampuku untuk. membuat suamiku tetap senang? (Hanaurumi, 1970: 22)

Berdasarkan kutipan percakapan itu sebagai awal pembentukan memori pada diri Gin. Bagaimanapun juga Gin sakit hati dicap tak bisa punya anak. Gin terpaksa mengakui bahwa dirinya ringkih. Selama menikah dia tidak dapat menjalankan kewajibannya sebagai istri dan menantu perempuan karena sakit. Namun, bukan penyakitnya yang menjadi awal dari keadaan itu. Suaminyalah yang telah memberikan penyakit itu kepadanya. Gin adalah korban.

「向うさまでも、申し訳ないと おっしゃってました」

[Mukau sama demo, moushiwakenai to osshattemashita]

Yab, mereka tadi minta maaf. (Hanaurumi, 1970: 39)

Kayo bicara lagi. Gin tidak lantas merasa lebih baik mendengar kalimat itu. Yang dilakukan semua laki-laki hanya meminta maaf. Lantas bagaimana dengan perempuan? Menerimanya sebagai takdir dan menyerah begitu saja?

$$
\text { 「向うさまでも体 があるだろう }
$$

[Mukau sama demo ga aru daroushi...]

Mereka juga perlu menjaga citra keluarga mereka, aku yakin begitu. (Hanauzumi, 1970: 38)

Lanjut Kayo, jelas menunjukkan bahwa citra merupakan sesuatu yang harus dipertimbangkan oleh keluarga Ogino juga.

$$
\begin{aligned}
& \text { 「とにかく、それが一番良いようで } \\
& \text { す」 }
\end{aligned}
$$

[Tonikaku, sore ga ichiban yoi youdesu]

Lagi pula, semuanya demi kebaikan.

(Hanauzumi, 1970: 38)

またも体面かとぎんは母を睨んだ。

Mata mo taimen ka to gin wa haha wo niranda.

Jadi, semua ini hanya masalah kehomatan, ya? Pikir Gin. (Hanauzumi, 1970: 38)

$$
\text { 「でも、だからといって・・・」 }
$$

[Demo, dakara to itte...]

Tapi, itu tidak berarti...

(Hanauzumi, 1970: 40).

Gin masih ingin membantah bahwa tertular penyakit yang tidak ada obatnya ini dari suaminya harus diterima begitu saja sebagai derita pribadi. Sebetulnya Gin sudah bisa mencium adanya perempuan idaman lain Kanichiro. Dia takkan pernah memaafkan suaminya. Perempuan yang selalu mendapat posisi menjadi korban dan menjadi aib bagi keluarga maupun masyarakat. Hal 
ini sesuai dengan kutipan pernyataan di bawah ini.

「お前には本当に悪いことをしま した。母さんからも謝ります」

[Omae ni wa hontou ni warui koto o shimashita. Baasan kara mo ayamarimasu]

Apa yang terjadi kepadamu adalah aib. Sebagai ibumu, aku minta maaf. (Hanauгumi, 1970: 40)

Gin dibawa ke Rumah Sakit Juntendo di Tokyo pada pertengahan Desember 1870, ditemani oleh Kayo, ibunya. Dan dokter segera memeriksanya.

\section{「局所を診察させていただく」}

[ Kyoku dokoro o shinsatsu sasete itadaku]

Mari kita periksa bagian yang terinfeksi. (Hanauzumi, 1970:63)

ぎんは眼を閉じる、血がでるほじ 唇を堅く噛んでいた。こんな所で 秘所を見られるくらいなら死んだ 方がよかった。たとえ医師とは言 え、恥ずかしいところを哯くなど ということが許されるのであろう か。しかしも相手は女ならまだし も男である。

[Gin wa manako o tojiru, chi ga deru hodo kuchibiru o kataku kandeita. konna tokoro de hitokoro o mirareru kurai nara shinda houga yokatta. Tatoe ishi to wa ie, hazukashii tokoro o nozokunado to iu koto ga yurusareru no de arouka. Shikashi mo aite wa onna nara mada shimo otoko de aru]

Gin memejamkan matanya dan menggigit bibir sampai terasa amis darah karena bibirnya terluka. Dia berpikir lebih baik mati daripada harus memperlihatkan bagian pribadinya kepada para laki-laki ini. Apakah dokter memang diperbolebkan melakukan hal-hal seperti itu? Kalau dokternya perempuan, pasti berbeda. Sunggub tak habis pikir seorang perempuan harus menunjukkan bagian pribadi tububnya kepada laki-laki seperti ini. (Hanauгumi, 1970:64)

Peristiwa beberapa menit kemudian terhapus seluruhnya dari ingatan Gin karena otaknya serta-merta kosong akibat syok dan rasa malu yang luar biasa dan sekaligus melatarbelakangi keinginannya untuk menjadi dokter perempuan. Gagasan itu tiba-tiba menggaung ke titik pusat jiwa Gin, mengisi kekosongan di dalam hatinya sebagai perempuan yang baru berumur sembilan belas tahun, hati seorang gadis kecil yang gagal dalam membina rumah tangga dan menghadapi masa depan yang nihil harapan. Pada tanggal 3 Januari, rumah sakit sudah kembali menjalankan aktivitas normal, termasuk pemeriksaan. Saat itu, mimpi baru saja tertanam di pikiran Gin mulai menghunjamkan akar-akarnya. Awalnya dia memang hanya berandai-andai, tetapi sekarang dia sudah yakin ingin menjadi seorang dokter. Bahkan sekarang hanya itulah satu-satunya keinginan yang memenuhi benaknya. Dia sama sekali tidak tahu bagaimana caranya mewujudkan impian tersebut, apalagi membayangkan apakah bakal berhasil, tapi dia bertekad ingin mencoba sebaikbaiknya. Dia sudah tak dapat lagi mendambakan kebahagiaan sebagai seorang perempuan normal, jadi dia bebas secara total memikirkan cara untuk mengejar impiannya.

Gin mendapatkan toleransi orang lain untuk pertama kalinya di Tokyo. Gin tidak lagi harus bersembunyi dari mata-mata yang mengintai dalam sebuah kelompok kecil yang mencekik, atau membaca buku dengan diam-diam dalam lingkungan yang menindas dan mencela. Gin merasa bebas untuk belajar atau melakukan apapun yang 
dia inginkan. Tidak ada yang menghalangi jalannya. Gin bisa melupakan bahwa dia janda. Semua orang menganggapnya sebagai seorang gadis muda yang masih lajang. Tidak ada pertanyaan-pertanyaan baginya dan dia tidak berkewajiban untuk menjelaskan siapa dirinya. Belajar memiliki prioritas yang tertinggi. Yang dilakukan Gin hanyalah belajar. Faktor lain di balik semangat barunya itu adalah bahwa penyakitnya tidak aktif. Semuanya berjalan sesuai dengan keinginan Gin.

Sejak awal Restorasi Meiji, bagaimanapun juga, ilmu kedokteran di Jepang telah berubah haluan dengan mengikuti ilmu kedokteran Barat. Sebagai reaksi akan hal ini, timbullah pergerakan untuk Pemulihan Ilmu Kedokteran China. Di permukaan, pemikiran Barat tampaknya disambut oleh masyarakat Jepang dengan tangan terbuka, tetapi kenyataannya di sektor tertentu, ilmu kedokteran tersebut ditentang keras oleh orang-orang yang menolak menerima apapun yang tidak dibesarkan dalam budaya Jepang. Pergerakan untuk Pemulihan Ilmu Kedokteran China adalah bagian dari sentiment anti-asing dan tujuannya adalah untuk mempromosikan ilmu kedokteran China, yang telah menjadi bagian dari budaya Jepang selama berabad-abad.

Gin mendapati siswinya yang bernama Ai keluar dari asrama di mana ia mengajar sementara. Mata Gin berkilauan. Meskipun masih belia, Ai pergi untuk menemui seorang laki-laki dan pulang terlambat, lalu memanjat dinding agar bisa masuk. Apakah yang telah membuatnya begitu ingin bertemu dengan laki-laki itu?
Ai telah menyerah kepada seorang laki-laki dan dengan demikian telah mempermalukan semua perempuan.

「婦人は男性とは違うのです、どん なことがあっても身を堅く保たねば いけません。身を堅く保てぬほどの 婦人はではありません」

[Fujin wa dansei to wa chigau no desu, donna koto ga attemo mi o kataku tamotaneba ikemasen. Mi o kataku tamotenu hodo no fujin wa dewa arimasen]

Perempuan berbeda dengan laki-laki. Tidak peduli bagaimanapun situasinya, kau harus selalu melindungi diri sendiri. Seorang perempuan yang tidak dapat melindungi dirinya tidak akan diperlakukan sebagai manusia. (Hanauzumi, 1970: 132)

Lebih lanjut Gin menambahkan bahwa yang diinginkan laki-laki hanyalah tubuh perempuan. Perempuan seharusnya mendapatkan pendidikan. Dengan pendidikan yang baik, perempuan bisa menjadi tipe orang yang tidak akan dibicarakan orang lain di belakangnya. Sikap mayoritas masyarakat terhadap pendidikan bagi perempuan terbukti pada ucapan-ucapan seperti Melabirkan anak perempuan yang suka belajat membawa aib pada selurub keluarga, Utamakan pelayanan daripada pelajaran dan Perempuan seharusnya diam di rumah. Karena alasan-alasan semacam itulah, gadis -gadis itu melawan keinginan orangtua mereka dan akibatnya beberapa bahkan tidak lagi diakui oleh keluarga mereka. Tiap-tiap pribadi tersebut merasa bangga dan berkemauan keras. Mereka adalah para perintis yang penuh semangat dengan keyakinan kuat bahwa mereka memikul masa depan pendidikan bagi perempuan di Jepang. Mereka juga dapat digambarkan sebagai kelompok perempuan muda yang berduri: semuanya memiliki 
semangat bersaing yang kuat dan sangat termotivasi. Gin, tentu saja merasa sangat nyaman berada di tengah-tengah mereka.

Aktivitas memori sering mengambil bentuk protes politik terhadap struktur budaya yang melekat pada masyarakat. Gin mengambil kesempatan untuk mengubah namanya menjadi "Ginko", sehingga menjadi Ginko Ogino. Sudah cukup lama dia merasa tidak puas dengan cara perempuan diberi nama yang singkat dan mudah dipanggil, seperti nama anjing saja. Dia tidak setuju dengan pemikiran yang ada saat itu bahwa satu-satuya kebutuhan bagi perempuan untuk memiliki nama hanyalah supaya berguna ketika suami atau ibu mertua ingin menyuruh mereka. Setelah sepuluh hari masuk sekolah pada semester itu, setelah memikirkan hal itu masak-masak, Gin mulai menulis namanya sebagai "Ginko". Hal ini sebagai permulaan identitas dirinya yang sesungguhnya. Seperti bukti kutipan pernyataan Gin berikut ini.

「女だって、男と同様に漢字で 堂々と書かれるべきである」

[Onna date, otoko to douyou ni kanji de dou dou to kakareru beki de aru]

Nama perempuan harus ditulis dengan buruf China yang bermartabat, sama seperti nama laki-laki (Hanawzumi, 1970: 147).

Sebagai perempuan pertama yang menerima surat izin untuk praktik kedokteran, Ginko menjadi selebriti dalam semalam karena kisahnya dimuat di koran dan majalah, yang semuanya memuji bakat akademis dan usaha kerasnya. Sebelumnya Ginko banyak dicemooh dan disebut sebagai perempuan eksentrik yang tidak tahu menempatkan diri. Pada Mei 1885,
Ginko membuka Klinik Obstetri dan Ginekologi Ogino di sebuah bangunan sederhana yang serupa dengan rumah-rumah kayu dan toko-toko di sekitarnya. Dalam waktu satu bulan setelah dibuka, Klinik Ogino meluap dikunjungi pasien. Ginko amat terkejut dengan banyaknya pasien yang berpenyakit kelamin. Seolah-olah semua perempuan yang secara diam-diam menyimpan gejala penyakit itu hingga sekarang berbondong-bondong maju ke depan. Karena mengenal penderitaan mereka dengan baik, Ginko memeriksa setiap pasiennya dengan lembut tetapi menyeluruh. Zaman itu dokter memiliki kewenangan dan status yang luar biasa, dan umumnya dokter laki-laki menanyai pasien mereka dengan cara-cara yang merendahkan. Namun, Ginko memperlakukan pasienpasiennya dengan hormat dan berbicara kepada mereka dengan sopan. Karena dia mendengarkan dan mengangguk dengan simpatik, pasien merasa mudah untuk berbicara dengannya dan bahkan sering menceritakan hal-hal lainnya yang sedang terjadi di rumahnya selain gejala penyakit mereka.

Kenyataannya, tidak semua pasien-pasien Ginko berkecukupan. Klinik Ginko berada di Yushima yang terletak di antara pusat kota yang ramai dan kawasan Yamanote, dan di antara orang -orang yang datang menemuinya terdapat buruh, pedagang kaki lima, musisi, dan bahkan pengemis, serta para istri dan gundik pedagang kaya. Orang yang sangat miskin jarang menemui dokter. Mereka mengandalkan obat dan ramuan yang tersedia tanpa resep, mereka baru akan mencari bantuan dokter kalau sudah putus asa. Ini terjadi terutama setelah tahu bahwa dokter itu adalah seorang perempuan baik hati yang tidak membeda-bedakan 
pasiennya. Dulu ada pepatah terkenal yang menyatakan bahwa "Kedokteran adalah sebuah seni berbaik hati", dan ini sangat diterapkan oleh Ginko, meskipun dia menempati status sangat tinggi seperti yang dinikmati para dokter era Meiji. Pada masa itu, tidak ada pengaturan tarif harga yang ditetapkan, baik untuk pemeriksaan maupun resep.

Sulit bagi kita saat ini untuk memahami betapa tinggi penghargaan akan profesi dokter era Meiji. Tidak peduli seberapa tinggi suhu tubuh seorang pasien, ketika dia mendengar bahwa dokter telah datang dia akan duduk, merapikan pakaiannya, dan menunggunya dengan hormat memasuki ruangan. Dia akan menekan rasa pusingnya untuk menyapa dokter dengan formalitas yang pantas, dan menjaga kepalanya tetap menunduk, sementara dokter memeriksa denyut nadinya. Ginko bersikap baik kepada para pasiennya bukan karena ingin disukai atau mendadak sifatnya berubah baik. Setiap kali Ginko mengobati pasien, dia teringat bagaimana rasanya sakit. Tidak jelas apakah dia melakukan ini dengan sadar karena gerakan dan tindakannya terlihat begitu wajar. Mungkin hal tersebut muncul karena perasaan empati seseorang yang pernah merasakan penderitaan orang lain.

Ginko akan menyapa pasien-pasiennya setiap kali berjumpa mereka di kota. Pada pertengahan era Meiji, para dokter lazimnya berkeliling dengan diangkut tandu atau angkong sehingga sangat langka menemukan dokter yang berjalan kaki di jalanan. Bagi kebanyakan orang, Ginko adalah dokter pertama yang pernah mereka lihat di kota, berbelanja sendiri, dan menyapa orang-orang yang dikenalnya. Reputasi Ginko makin berkembang hari demi hari, dan dia bekerja keras dari pukul Sembilan pagi sampai pukul delapan malam menangani pasien di klinik dan menerima panggilan ke rumah-rumah.

\section{Memaafkan "Kekhawatiran yang Hilang"}

Kesulitan utama Ginko berasal dari jenis kelaminnya. Dia menjadi satu-satunya perempuan di sekolah khusus laki-laki. Walaupun pengaruh Eropa telah memengaruhi kelas masyarakat tertentu, budaya Eropa tersebut tidak menyentuh kehidupan rakyat jelata. Butuh waktu bertahuntahun untuk mengubah pemikiran konservatif yang dibudidayakan selama tiga ratus tahun zaman Tokugawa. Kesulitan yang dialami Ginko sama dengan yang dihadapi oleh semua perempuan perintis modernisasi lainnya, meskipun dalam kasusnya, diskriminasi dapat dikategorikan sebagai penganiayaan secara aktif. Dan karena semua penghinaan itulah Ginko bisa bertahan. Gin berdamai dengan masa lalunya itu. Hal tersebut didukung dengan kutipan narasi di bawah ini.

「終了証書をうけ、通いなれた練塀 町の坂を下りながら、吟子は再び順 天堂の気の遠くなるような羞恥の瞬 間を思い出していた。それは日を経 るにつれ一層鮮やかに吟子に㝿って くる。その瞬間をいま吟子は憎んで いないが、といって忘れたわけでも ない。事実は事実としてはっきりと 心にとどめておこうと思う。その屈 辱がいまとなっては、吟子の励みと なっていた。よくもまあ通い了せた ものだ。三年間頑張り続けた自分で 愛おしく、思いきり賞めてやりた かった。だが吟子の戦いはこれで 終ったのではなかった。戦いはいよ 
いよこれからが本番であった。」

[Shuuryou shousho o uke, kayoi nareta neribeichou no saka o orinagara, ginko wa futatabi juntendou de no ki no tookunaru youna shuuchi no shunkan o omoi dashiteita. Sore wa hi o heru nit sure ichi sou azayakani ginko ni yomigaettekuru. Sono shunkan o ima ginko wa nikundeinaiga, toitte wasureta wakedemonai. Jijitsu wa jujitsu toshite hakkiri to kokoro ni todomete okou to omou. Sono kutsujoku ga ima to natte wa, ginko no hagemi to natteita. Yoku mo maa kayoi ooseta mo noda. Minenkan ganbari tsuzuketa jibun ga jibun de itooshiku, omoi kiri homete yaritakatta. Daga ginko no tatakai wa kore de shimatta no de wa nakatta. Tatakai wa iyo iyo korekara ga honban de atta.]

Berjalan di daerah Neribei yang sekarang telab dikenalnya dengan baik, dan dengan ijazab Kojuin di tangan, Ginko mengingat rasa malu akibat pemeriksaan fisik yang pernah dialaminya di Rumah Sakit Juntendo. Dengan berlalunya waktu, jaub dari memudar, ingatan itu kembali dengan semakin jelas kepadanya. Ginko tidak lagi melihat ke belakang ke masa itu dengan kebencian, tapi dia juga tidak akan lupa. Ingatan itu adalah kenyataan dan Ginko ingin memastikan bahwa ingatan itu terukir dengan tegas di dalam hatinya. Penghinaan itu dengan cara tertentu menjadi pemacu baginya, yang selalu mendorongnya. Ginko merasa bangga kepada dirinya dan pada apa yang telah dicapainya. Namun, pertempurannya belum selesai. Pertempuran itu baru saja dimulai. (Hanauzumi, 1970: 223-224)

\section{Pada hari Minggu awal bulan Novem-}

ber, Ginko mendapat kesempatan untuk berbicara panjang dengan pendeta Ebina. Pendeta itu lima tahun lebih muda, tetapi Ginko menganggapnya sebagai orang yang lebih dewasa dalam banyak hal. Ginko bercerita kepadanya mengenai diskriminasi yang dialami dalam perjalanannya untuk menjadi dokter, dan bagaimana dia merasa bahwa hanya dirinya sendirilah yang harus mengalami cobaan seperti itu. Pendeta Ebina mengangguk tanpa menjawab untuk mendorong Ginko berbicara lebih banyak lagi tentang perasaannya.

「今まで、私は私自身のことしか眼 中にありませんでした。一日も早く 一刻も早く、女医者になる。そして 女なるが故に受けた屈辱を見返して やる。表では女の患者の屈辱を救っ てやろうと願いながら、心の底では 見返してやろらといら復售心でし た。辱しめを与えた男へは勿論、私 を除け者にした家族や親戚、郷里、 友達、そして自分自身に対してもで す。復售するまでは頑張ろうと思い ました。でも誰にも負けまいという のは裏を返せば自分だけ抜きん出よ うという功名心でした。自分だけ磨 き、自分だけ秀でた知識を得たいと 思いました。女医者になり社会的地 位さえ得られればすべては解決する のだと思っていました。自分一人の 実に小さなものに私はかかずり合っ ていたのです」

IIma made, watashi wa watashi jishin no koto shika ganchuu ni arimasendeshita. Tsuitachi mo hayaku ikkoku mo hayaku, onna isha ni naru. Soshite onna naru ga yue ni uketa kutsujoku o mikaeshiteyaru. Okite de wa onna no kanja no kutsujoku o sukutte yarou to negai nagara, kokoro no tei de wa mikaeshite yarou to iu fukushuushin deshita. Hazukashime o ataeta otoko e wa mochiron, watashi o noke mono ni shita kazoku ya Shinseki, kyouri, tomodachi, soshite jibun jishin ni taishitemo desu. Fukushuu suru made wa ganbarou to omoimashita. Demo dare ni mo makemai to iu no wa ura o kaeseba jibun dake nukin deyou to iu koumyoushin deshita. Jibun dake migaki, jibun dake sugureta chishiki o etai to omoimashita. Onna isha ni nari shakaiteki chikuraisae erare rebasubete wa kaiketsu suru no da to omotte imashita. Jibun hitori no jitsu ni 
chiisana mono ni watashi wa kakazuri atteita no desu] Aku tidak pernah memikirkan siapa pun selain diriku sendiri. Yang ada dalam pikiranku hanyalah bagaimana menjadi dokter sehingga aku bisa memandang rendah orang -orang yang menyakitiku. Di permukaan, aku ingin menyelamatkan pasien perempuan lain dari penghinaan yang aku derita, tetapi jauh di lubuk hati, aku ingin membalas dendam. Aku ingin membalas semua laki-laki yang membuatku menderita dan orang-orang yang memperlakukanku sebagai orang buangan keluargaku dan kerabat, kota tempatku dibesarkan, bahkan kepada diriku sendiri. Aku menyangka dengan mengetabui lebih banyak dan menjadi lebih hebat daripada siapa pun akan dapat menyelesaikan semua masalabku. Aku akan memiliki status sosial seorang dokter yang terhormat. Ternyata itu hanya membuktikan betapa kecilnya diriku. (Hanaurumi, 1970: 354)

Sosok Yesus Kristus tergantung di dinding tepat di belakangnya, Ginko merasa mata Yesus dan juga Ebina sedang memandangnya. Ginko bisa mengobrol dengannya dengan sejujur-jujurnya. Ginko tidak pernah memikirkan siapa pun selain dirinya sendiri hingga tujuan hidupnya tercapai. Dan ketika semuanya telah berada di dalam genggaman, Ginko memperhatikan ketidaksempurnaan orang-orang. Begitupun juga dirinya, di balik kemalangan seorang perempuan terdapat tirano seorang laki-laki dan Ginko membenci laki-laki karena hal tersebut. Ginko mengaku dosa dan memohon pengampunan. Ebina meyakinkannya bahwa Manusia tidak sepenuhnya melawan kehendak Tuhan. Mereka justru semakin berpegang teguh pada-Nya ketika tenggelam lebih jauh ke dalam dosa. Pada saat-saat seperti itulah manusia benar-benar merindukan Tuhan. Tuhan kita adalah Tuhan pribadi, penuh cinta, dan saat inilah kita mampu bergabung dengan-Nya dalam hubungan seperti orangtua dan anak. Pendekatan inklusif Ebina itu berhasil membujuk Ginko dan membuatnya mengambil keputusan untuk memeluk agama Kristen. Ebina membaptisnya pada November 1885.

\section{Kesimpulan}

Memori dan pengampunan direpresentasikan dalam novel Hanauzumi sebagai alat memungkinkan Gin untuk menerapkan karakter kuat dan berani di dalam dirinya. Pembentukan memori pada diri Gin bermula saat ia menderita penyakit kelamin yang terinfeksi dari suaminya yang telah mengkhianati pernikahan mereka. Setelah bercerai, Gin dibawa berobat ke Rumah Sakit Juntendo dan mengalami peristiwa traumatis yang mendalam ketika bagian tubuhnya yang terinfeksi diperiksa oleh dokter laki-laki karena pada era itu belum ada dokter perempuan di Jepang. Lebih jauh lagi akhirnya Gin memutuskan untuk menjadi dokter perempuan pertama di Jepang. Hal yang terbilang mustahil untuk dilakukan pada masa itu, di mana baik pemerintah maupun masyarakat pedesaan masih memusuhi perempuan yang senang belajar. Hal tersebut dikarenakan arus modernisasi belum menyentuh daerah-daerah pedesaan yang masih mengakar kuat cara pemikiran yang lama. Dan pada akhirnya Ginko memaafkan dan berdamai dengan masa lalunya. Karena jika tidak ada peristiwa masa lalunya itu, ia tidak akan berhasil memegang ijazah kedokteran dan membuka praktik dokternya. Selain itu keseluruhan hidupnya yang selama ini penuh dengan egosentris, hanya dirinya yang ia pikirkan, telah membuatnya sadar dan merasakan akan adanya kelelahan hati dan 
kekosongan jiwa. Hingga pada akhirnya Pendeta Ebina membaptisnya menjadi pemeluk agama Kristen.

Novel Hanauzumi bisa dikatakan memang bukan 100\% novel yang bertemakan postmemory. Tapi menurut pandangan penulis, tokoh utama Gin yang merubah namanya menjadi Ginko menandakan identitas barunya dan sebagai post generasi yang mentransmisikan peristiwa traumatis mendalamnya kepada perempuan lainnya yang walaupun tidak ada hubungan keluarga dengannya, namun transmisi memorinya tersebut membawa pesan kepada generasi selanjutnya. Pesan nyata yang merepresentasikan bahwa dibalik eksploitasi seks, gender, pendidikan maupun hak politik yang diterima oleh kaum perempuan selama lebih dari 350 tahun masa Tokugawa hingga transisi kekuasaan menuju Kekaisaran Meiji, dengan adanya keberanian mendobrak dan melawan struktur pemikiran lama yang telah mengakar kuat dan juga memperjuangkannya, terbukti bahwa perempuan dapat juga menerima keadilan haknya dan meraih apa yang dicitacitakannya. Salah satu contohnya yaitu Gin yang berposisi sebagai post generasi yang mentransmisikan peristiwa traumatisnya itu secara narasi kepada muridnya yang bernama Ai supaya tidak mengalami peristiwa seperti yang telah dialaminya dulu saat seumuran dengannya.

Wacana yang dimengerti sebagai bahasa digunakan Ginko untuk merepresentasikan praktik kekuasaan dari sudut pandangnya sebagai dokter maupun sebagai perempuan. Bagaimana Ginko sebagai dokter dengan kekuasaan yang dimilikinya mampu memberikan analisanya terhadap penyakit yang diderita pasiennya. Ginko sebagai dokter dapat menggunakan kuasanya untuk menentukan seorang pasien harus dirawat inap atau hanya dirawat jalan saja. Hal tersebut merupakan refleksi praktik diskursus yang nyata dari pihak Ginko sebagai pihak yang berkuasa. Walaupun Ginko memiliki status yang tinggi karena dirinya seorang dokter, tapi ia tetap menggunakan kuasanya itu dengan cara baik dan bijak kepada pasiennya. Ginko menampilkan representasi profesi dokter yang berbeda dari citra dokter yang selama ini terkesan dingin dan arogan. Ginko menjadi dokter idaman yang secara ikhlas menyalurkan rasa empatinya kepada setiap pasien yang ia temui. Berangkat dari peristiwa traumatis masa lalu yang pernah dialaminya sendiri, bagaimana ia merasakan sakit sehingga ia juga memperlakukan pasien-pasiennya dengan lembut namun menyeluruh.

\section{Daftar Pustaka}

Creswell, John W, 2008, Research Design, Pendekatan Kualitatif, Kuantitatif, dan Mixed. Bandung: Pustaka Pelajar

Fernanda, Andri. 2017. Transmisi Memori dan Trauma dalam Motherland Karya Dimetri Kakmi: Kajian Postmemory. Universitas Gajah Mada. Tesis.

Gorska, Ewa. 2016. "Memory Activism: Methods of Creation of Alternative Collective Memory in Former Yugoslavia and Israel”. Maska, Vol. 32:7-19.

Hirsch, Marianne. 2008. "The Generation of 
Postmemory". Poetics Today, Vol. 29, No. 1:103-128

Ingham, Lydia Alix Fill. 2001. Foucault untuk Pemula. Yogyakarta: Kanisius

Kumalasari, Isti. 2016. "Membaca Gender Dalam Konteks Postmemory”. Poetika, Vol. IV, No. 1:61-63.

Lazzara, Michael. J. 2009. “(Post) Memory, Subjectivity, and The Performance of Failure in Recent Argentine Documentary Films". Latin American Perspective, Vol. 36, No. 5:147-157.

Nora, P., (1989), "Between Memory and History: Les Lieux de Mémoire", Representations, 26 (Special issue: Memory and Counter-Memory): 7-25.

Pytko, Aleksandra. 2016. "The Power of Memory and The (Im)Possibility of Forgiveness in "The Tempest" (2003) Directed by Krzysztof Warlikowski”. Maska, Vol. 32:61-69.

Raco, J.R. 2013. Metode Penelitian Kualitatif Jenis Karakteristik dan Keunggulannya. Jakarta: Grasindo.

Sik, Domonkos. 2015."Memory Transmission and Political Socialization in PostSocialist Hungary". The Sociological Review, Vol. 63:53-71.

Syahputra, Iswandi. 2010. "Post Media Literacy: Menyaksikan Kuasa Media Bersama Michael Foucault”. ASPIKOM, Vol. 1, No. 1: 1-24

Watanabe, Jun'ichi. (1970). Hanauzumi. Japan: Shinchousha.
(2012). Ginko. (Terjemahan Istiani Prajoko). Japan: Shinchousha. (Buku asli diterbitkan tahun 1970). 